\title{
Genetic diversity of Zingiber officinale (Zingiberaceae) germplasm grown in urban and rural backyards in Mato Grosso, Brazil
}

\author{
E.S. Cardoso ${ }^{1,2,3}$, A.A.B. Rossi ${ }^{1,2,3}$, E.C.M. Pedri ${ }^{1,2,3}$, K.E.M. Zortéa ${ }^{1,3}$, \\ A.V. Tiago ${ }^{1,2,3}$, V.D. Rocha ${ }^{4}$, A.S. Rodrigues ${ }^{5}$ and U.A. Oliveira ${ }^{6}$ \\ ${ }^{1}$ Universidade do Estado de Mato Grosso Carlos Alberto Reyes Maldonado, \\ Faculdade de Ciências Biológicas e Agrárias, Centro de Pesquisa e \\ Tecnologia da Amazônia Meridional, Laboratório de Genética Vegetal e \\ Biologia Molecular, Campus de Alta Floresta, MT, Brasil \\ ${ }^{2}$ Programa de Pós-Graduação em Biodiversidade e Agroecossistemas \\ Amazônicos, Alta Floresta, MT, Brasil \\ ${ }^{3}$ Programa de Pós-Graduação em Biodiversidade e Biotecnologia da Rede \\ Bionorte/UNEMAT, Alta Floresta, MT, Brasil \\ ${ }^{4}$ Programa de Pós-Graduação em Genética e Melhoramento/UFV, Viçosa, \\ MG, Brasil \\ ${ }^{5}$ Programa de Pós-Graduação em Genética e Melhoramento de \\ Plantas/UENF, Campos dos Goytacazes, RJ, Brasil \\ ${ }^{6}$ Programa de Pós-Graduação em Biotecnologia Vegetal/UENF, Campos dos \\ Goytacazes, RJ, Brasil
}

Corresponding author: E.S. Cardoso

E-mail: elisabyo@gmail.com

Genet. Mol. Res. 19 (2): gmr18576

Received February 16, 2020

Accepted April 30, 2020

Published May 31, 2020

DOI http://dx.doi.org/10.4238/gmr18576

\begin{abstract}
Ginger (Zingiber officinale Roscoe) is a selfincompatible plant and has high rates of infertility; its genetic diversity only occurs via processes of mutation and natural selection. Since ginger is important as a condiment and as an herbal medicine, understanding its diversity to a greater degree can contribute both to its conservation and to its use in breeding programs. Considering the importance of the species and the characterization of material from on-farm conservation, this study aimed to evaluate, by means of ISSRs (Inter Simple Sequence Repeats) molecular markers of genetic diversity among individuals obtained in 19 urban and rural backyards
\end{abstract}


in Alta Floresta, Mato Grosso state, Brazil. For the extraction of total DNA, the CTAB method was used and the amplifications were performed using nine ISSR primers. The UPGMA clustering method, when compared with the Ward and Nearest Neighbor methods, best showed genetic diversity, and the Bayesian analysis defined two distinct groups in the $Z$. officinale germplasm that was evaluated. The ISSR primers amplified a total of 78 fragments and revealed $88 \%$ polymorphism. The PIC varied between 0.40 and 0.87 , with an average of 0.70 , and was classified as median in the detection of polymorphism. The most dissimilar individuals were AF06 and AF12, while the least dissimilar were AF06 and AF04. The Nei (He) and Shannon (I) diversity indices demonstrated genetic variability within the two groups formed from the Bayesian analysis, and AMOVA indicated that the genetic diversity was greater within the groups $(53.06 \%)$ than among them $(46.94 \%)$. The absence of duplicates among the individuals analyzed indicates that they can be used to form an active germplasm collection with the aim of conserving and maintaining the genetic diversity of the species.

Key words: Molecular characterization; Ginger; ISSR; Genetic resources

\section{INTRODUCTION}

Zingiber officinale Roscoe, popularly known as ginger, has culinary and medicinal properties, and in Brazil it is grown commercially in the states of São Paulo, Espírito Santo, Paraná and Santa Catarina (Palharin et al., 2008; Sousa et al., 2013). The main varieties of Z. officinale cultivated commercially in Brazil are the Hawaiian, Jamaican, Takahashi, IAC, Chinese giant and Japanese giant, the latter two being the most common in plantations for the export market (Elpo, 2008).

The wide use of $Z$. officinale as a condiment, its increasing use as a traditional herbal medicine and its exploration by the pharmaceutical industry encourage studies related to the specie. However, the majority of studies focus on culinary and medicinal properties while there is little information related to the genetic heritage of the specie, its characterization and variability.

Z. officinale originated in Asia and was distributed to several countries via plant propagation, since it is a species that does not produce seeds (Magalhães et al., 1997; Adaniya and Shoda, 1998). It is an herbaceous, perennial plant with zygomorphic and monoclinic flowers. The species is diploid $(2 \mathrm{n}=2 \mathrm{x}=22)$, classified as self-incompatible, with high rates of infertility and exclusively vegetative propagation, so that its genetic variability comes principally from the processes of random mutation and natural selection (Adaniya and Shoda, 1998; Blanco et al, 2016).

Species that reproduce asexually, such as $Z$. officinale, tend to maintain their genetic makeup over generations (Xavier et al., 2013). However, when they are cultivated in different regions, distinct genotypes can occur since they will have originated from natural mutations that occurred throughout its evolutionary history. As such, they are often adapted to the local environmental conditions. Thus, the cultivation of these species on 
small properties to supply local trade or in backyards (urban or rural), for the grower's own consumption, as often occurs in Mato Grosso, is characterized as an "on farm" diversity conservation system, which, through management and use techniques, contributes to the diversification of genetic resources (Santonieri and Bustamante, 2016).

The characterization and evaluation of the genetic material from $Z$. officinale grown in urban or rural backyards allows for the identification and selection of genotypes that can compose germplasm collections, and thus guarantee the conservation of the diversity of the species. Moreover, it allows for the identification of useful characteristics for exploitation in breeding programs.

The characterization and evaluation of genetic diversity is commonly performed using morphological, physiological and molecular markers. The different types of molecular markers, whether enzymatic or based on nucleic acids, are distinguished by the technology used, by the power of resolution and by their applicability. Molecular characterization, based on nucleic acids, is a fast and effective tool, which is not influenced by the environment and identifies the polymorphism directly at the DNA level (Bered et al., 1997; Blanco et al., 2016).

Studies regarding the genetic diversity of $Z$. officinale have already been carried out using dominant markers such as RAPD (Random Amplified Polymorphism DNA) (Nayak et al., 2005; Kizhakkayil and Sasikumar, 2010), AFLP (Amplified Fragment Length Polymorphism) (Blanco et al., 2016) and ISSR (Inter Simple Sequence Repeats) (Kizhakkayil and Sasikumar, 2010; Pandotra et al., 2013; Pandotra el al., 2015; Ismail et al., 2016), and these studies indicate that, even though it is a species of vegetative propagation, it presents both intra and interpopulation genetic variations.

Using ISSR molecular markers, this study aimed to analyze the genetic diversity in Z. officinale germplasm obtained from samples taken from urban and rural backyards in the municipality of Alta Floresta, Mato Grosso state, Brazil.

\section{MATERIAL AND METHODS}

\section{Study area and collection of plant material}

Leaf plant material of $Z$. officinale was collected from urban and rural backyards in the municipality of Alta Floresta, Mato Grosso state, Brazil, where it is grown for household consumption. For the analysis using molecular markers, young leaves were collected from 19 individuals of $Z$. officinale. These came from backyards located in the five different urban areas and 14 rural areas, where they are grown for the grower's own consumption and where the material for propagation has been conserved by the growers for several years. The material was stored in aluminum foil envelopes, labeled, stored on ice and transported to the laboratory of Plant Genetics and Molecular Biology of UNEMAT in Alta Floresta, where it was stored at $-20^{\circ} \mathrm{C}$ until use. The urban and rural backyards in which the $Z$. officinale samples were obtained were georeferenced (GPS Garmin Etrex ${ }^{\circledR}$ ) (Figure 1). 


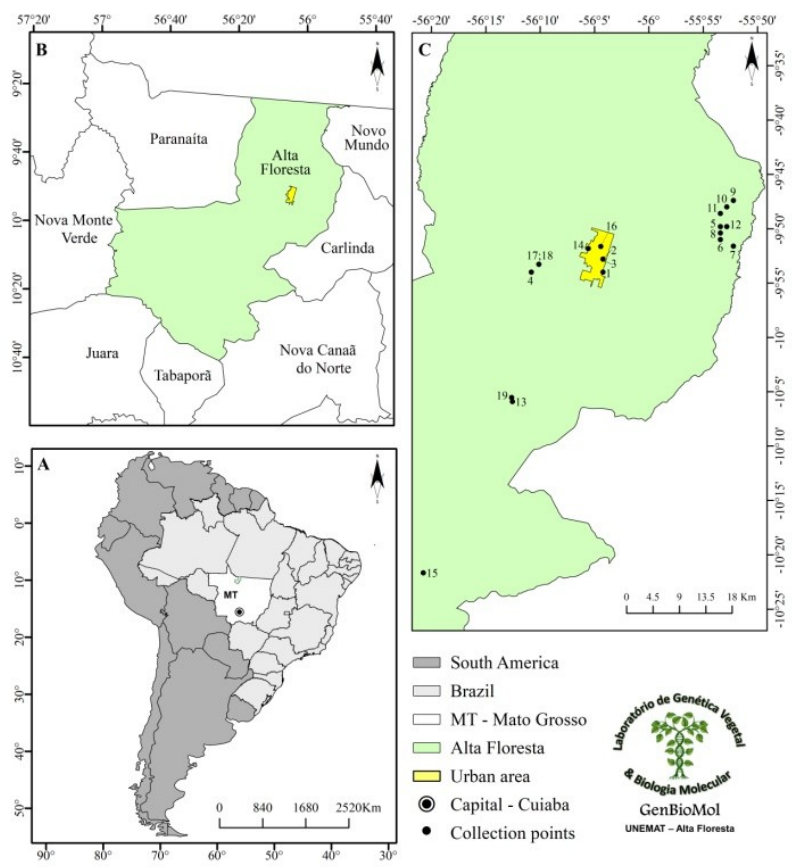

Figure 1. Geographic location of the collection points of the Zingiber officinale samples obtained in the municipality of Alta Floresta, Mato Grosso state, Brazil.

\section{DNA extraction and amplification by polymerase chain reaction (PCR)}

Total DNA extraction followed the CTAB protocol (Cationic Hexadecyltrimethyl Ammonium Bromide) described by Doyle and Doyle (1987), with some modifications in the extraction buffer, such as the addition of $2 \%$ polyvinylpyrrolidone (PVP) and an increase from 2 to $5 \%$ and from 0.2 to $2 \%$ in the concentrations of CTAB and $\beta$ mercaptoethanol, respectively. For DNA amplification, 40 ISSR (Inter Sequence Simple Repeats) primers, developed by the University of British Columbia (UBC), Vancouver, Canada, were tested. After amplification tests, nine primers were selected. These resulted in greater polymorphism and number of bands for molecular characterization of the 19 individuals.

The amplification reactions via the polymerase chain reaction (PCR) were performed in a final volume of $13.5 \mu \mathrm{L}$, containing $1.5 \mu \mathrm{L}$ of $10 \mathrm{x}$ buffer $(1 \mathrm{M} \mathrm{KCl} ; 1 \mathrm{M}$ Tris $\mathrm{pH} 8.3 ; 10 \%$ Tween 20$), 1.5 \mu \mathrm{L}$ of $\mathrm{MgCl}_{2}(25 \mathrm{mM}), 1.5 \mu \mathrm{L}$ of primer $(0.2 \mathrm{mM}), 1,5 \mu \mathrm{L}$ of dNTP (1.0 mM of each dNTP), $0.5 \mu \mathrm{L}$ of DNA (primer 809 ) or $1.0 \mu \mathrm{L}$ of DNA (primers 828 and 835 ) or $2.0 \mu \mathrm{L}$ of DNA (primers $808,818,829,834$ and 840 ) or $3.0 \mu \mathrm{L}$ of DNA (primer 826 ), $0.12 \mu \mathrm{L}$ of Taq polymerase $\left(5 \mathrm{U}^{-1} \mathrm{~L}^{-1}\right)$ and $\mathrm{H}_{2} \mathrm{O}$ Mili-Q. The reactions were carried out in an Eppendorf thermal cycler using the program proposed by Rocha et al. (2017), with the following amplification conditions: an initial denaturation cycle at $94^{\circ} \mathrm{C}$ for $4 \mathrm{~min}$, followed by 35 cycles of $1 \mathrm{~min}$ at $94^{\circ} \mathrm{C}, 1 \mathrm{~min}$ at $50-52^{\circ} \mathrm{C}$ (depending on the primer), $3 \mathrm{~min}$ at $72^{\circ} \mathrm{C}$, ending with a final extension at $72^{\circ} \mathrm{C}$ for $7 \mathrm{~min}$. 


\section{Data analysis}

The presence (1) and absence (0) matrix of the amplified fragments was used to calculate the percentage of polymorphism, and the polymorphic information content (PIC) of each primer was obtained by using the equation proposed by Hoffmann and Barroso (2006). The genetic dissimilarity matrix between each pair of individuals was calculated using the complement of the Jaccard index.

Cluster analysis using UPGMA (Unweighted Pair Group Method Average), Ward and NN (Nearest Neighbor) hierarchical methods was carried out on the dissimilarity matrix and the choice of the method with greater consistency of grouping was based on the cophenetic correlation coefficient (CCC), lower stress and distortion. The analyses were performed using the GENES program (Cruz, 2016). The genetic relationships between all the individuals evaluated were visualized via the Principal Coordinate Analysis (PCoA), based on the genetic distances of the matrix, using the GenAIEx program (Peakall and Smouse, 2012). The program Structure (Pritchard et al., 2000), based on Bayesian analysis, was used to infer population structure, indicate distinct genetic groups $(\mathrm{K})$ and assign individuals to these groups. For the definition of the most likely $\mathrm{K}$ in relation to those proposed, the criteria described by Pritchard et al. (2010) and Evano et al. (2005) were employed.

To characterize the genetic variability between the two groups constituted by the Bayesian analysis, Nei (He) genetic diversity, Shannon's diversity index (I) and the percentage of polymorphic bands (\% P) were calculated using the POPGENE 1.32 program (Yeh et al., 2000). The genetic diversity between and within the groups was demonstrated using AMOVA (Molecular Variance Analysis), according to Excoffier et al. (1992) and with the aid of the Arlequin 3.0 program (Excoffier et al., 2007).

\section{RESULTS}

The nine ISSR primers amplified 78 fragments, of which $88 \%$ were polymorphic. The number of amplified fragments varied between three (UBC 834) and 18 (UBC 835), with an average of 8.67 per primer and the polymorphic information content of each primer varied between 0.40 (UBC 834) and 0.87 (UBC 818 and UBC 829) (Table 1).

Table 1. List of ISSR primers used in the molecular characterization of the 19 individuals of Zingiber officinale.

\begin{tabular}{|c|c|c|c|c|c|}
\hline Primer & Sequence (5'-3') & AT $\left({ }^{\circ} \mathrm{C}\right)$ & NTB & $\% \mathrm{P}$ & PIC \\
\hline UBC 808 & AGAGAGAGAGAGAGAGC & 52 & 9 & 88.89 & 0.74 \\
\hline UBC 809 & AGAGAGAGAGAGAGAGG & 52 & 7 & 100.00 & 0.71 \\
\hline UBC 818 & CACACACACACACACAG & 52 & 7 & 85.71 & 0.87 \\
\hline UBC 826 & ACACACACACACACACC & 52 & 5 & 80.00 & 0.57 \\
\hline UBC 828 & TGTGTGTGTGTGTGTGA & 50 & 14 & 92.86 & 0.79 \\
\hline UBC 829 & TGTGTGTGTGTGTGTGC & 52 & 8 & 100.00 & 0.87 \\
\hline UBC 834 & AGAGAGAGAGAGAGAGYT* & 52 & 3 & 66.67 & 0.40 \\
\hline UBC 835 & AGAGAGAGAGAGAGAGYC* & 52 & 18 & 94.44 & 0.76 \\
\hline UBC 840 & GAGAGAGAGAGAGAGAYT* & 50 & 7 & 57.14 & 0.56 \\
\hline Total & - & - & 78 & 88.46 & \\
\hline Mean/Primer & - & - & 8.67 & 88.46 & 0.70 \\
\hline
\end{tabular}


The values of genetic dissimilarity, estimated from the complement of the Jaccard index, varied between 0.32 and 0.81 (Table 2), with the lowest dissimilarities found in this study occurring between individuals AF04 and AF06 and between AF18 and the AF19, while the individuals AF06 and AF12 were the most dissimilar.

Table 2. Genetic dissimilarity matrix between 19 individuals of Zingiber officinale. Calculation was based on the complement of the Jaccard index. 78 ISSR fragments were used.

\begin{tabular}{|c|c|c|c|c|c|c|c|c|c|c|c|c|c|c|c|c|c|c|c|}
\hline $\begin{array}{c}\text { AF01 } \\
0\end{array}$ & $\begin{array}{c}\text { AF02 } \\
0.44\end{array}$ & $\begin{array}{c}\text { AF03 } \\
0.44\end{array}$ & $\begin{array}{c}\text { AF04 } \\
0.42\end{array}$ & $\begin{array}{c}\text { AF05 } \\
0.52\end{array}$ & $\begin{array}{c}\text { AF06 } \\
0.54\end{array}$ & $\begin{array}{c}\text { AF07 } \\
0.57\end{array}$ & $\begin{array}{c}\text { AF08 } \\
0.67\end{array}$ & $\begin{array}{c}\text { AF09 } \\
0.60\end{array}$ & $\begin{array}{c}\text { AF10 } \\
0.69\end{array}$ & $\begin{array}{c}\text { AF11 } \\
0.62\end{array}$ & $\begin{array}{c}\mathbf{A F 1 2} \\
0.76\end{array}$ & $\begin{array}{c}\text { AF13 } \\
0.66\end{array}$ & $\begin{array}{c}\text { AF14 } \\
0.67\end{array}$ & $\begin{array}{c}\text { AF15 } \\
0.70\end{array}$ & $\begin{array}{c}\text { AF16 } \\
0.64\end{array}$ & $\begin{array}{c}\text { AF17 } \\
0.64\end{array}$ & $\begin{array}{c}\text { AF18 } \\
0.66\end{array}$ & $\begin{array}{c}\text { AF19 } \\
0.59\end{array}$ & $\mathrm{AF} 01$ \\
\hline \multirow{18}{*}{0} & $\begin{array}{c}0.44 \\
0\end{array}$ & $\begin{array}{l}0.44 \\
0.43\end{array}$ & $\begin{array}{l}0.42 \\
0.46\end{array}$ & $\begin{array}{l}0.22 \\
0.47\end{array}$ & $\begin{array}{l}0.54 \\
0.49\end{array}$ & 0.57 & 0.07 & $\begin{array}{l}0.00 \\
0.61\end{array}$ & $\begin{array}{l}0.09 \\
0.64\end{array}$ & $\begin{array}{l}0.02 \\
0.57\end{array}$ & 0.65 & 0.63 & 0.64 & 0.67 & $\begin{array}{l}0.04 \\
0.64\end{array}$ & 0.69 & $\begin{array}{l}0.00 \\
0.72\end{array}$ & 0.59 & $\mathrm{AF} 02$ \\
\hline & & 0 & 0.37 & 0.43 & 0.52 & 0.54 & 0.57 & 0.58 & 0.67 & 0.59 & 0.66 & 0.58 & 0.51 & 0.63 & 0.60 & 0.58 & 0.60 & 0.56 & $\mathrm{AF} 03$ \\
\hline & & & 0 & 0.47 & 0.32 & 0.54 & 0.61 & 0.65 & 0.66 & 0.59 & 0.72 & 0.65 & 0.68 & 0.65 & 0.67 & 0.68 & 0.59 & 0.58 & AF04 \\
\hline & & & & 0 & 0.44 & 0.49 & 0.58 & 0.69 & 0.69 & 0.66 & 0.73 & 0.63 & 0.63 & 0.73 & 0.66 & 0.66 & 0.71 & 0.67 & AF05 \\
\hline & & & & & 0 & 0.42 & 0.54 & 0.74 & 0.58 & 0.56 & 0.81 & 0.64 & 0.70 & 0.74 & 0.68 & 0.70 & 0.67 & 0.66 & AF06 \\
\hline & & & & & & 0 & 0.53 & 0.67 & 0.62 & 0.65 & 0.74 & 0.67 & 0.54 & 0.74 & 0.62 & 0.64 & 0.66 & 0.66 & AF07 \\
\hline & & & & & & & 0 & 0.46 & 0.39 & 0.47 & 0.54 & 0.51 & 0.53 & 0.56 & 0.49 & 0.63 & 0.55 & 0.61 & AF08 \\
\hline & & & & & & & & 0 & 0.52 & 0.43 & 0.42 & 0.51 & 0.46 & 0.53 & 0.57 & 0.58 & 0.56 & 0.56 & AF09 \\
\hline & & & & & & & & & 0 & 0.39 & 0.62 & 0.40 & 0.52 & 0.57 & 0.45 & 0.59 & 0.54 & 0.50 & $\mathrm{AF} 10$ \\
\hline & & & & & & & & & & 0 & 0.48 & 0.41 & 0.50 & 0.41 & 0.42 & 0.57 & 0.55 & 0.48 & $\mathrm{AF} 11$ \\
\hline & & & & & & & & & & & 0 & 0.50 & 0.54 & 0.52 & 0.61 & 0.58 & 0.45 & 0.57 & $\mathrm{AF} 12$ \\
\hline & & & & & & & & & & & & 0 & 0.39 & 0.37 & 0.47 & 0.51 & 0.53 & 0.49 & AF13 \\
\hline & & & & & & & & & & & & & 0 & 0.54 & 0.43 & 0.46 & 0.60 & 0.59 & AF14 \\
\hline & & & & & & & & & & & & & & 0 & 0.45 & 0.63 & 0.50 & 0.44 & AF15 \\
\hline & & & & & & & & & & & & & & & 0 & 0.46 & 0.47 & 0.47 & AF16 \\
\hline & & & & & & & & & & & & & & & & 0 & 0.50 & 0.56 & AF 17 \\
\hline & & & & & & & & & & & & & & & & & 0 & 0.32 & AF 18 \\
\hline & & & & & & & & & & & & & & & & & & 0 & AF19 \\
\hline
\end{tabular}

Among the clustering methods tested (UPGMA, WARD and NN), UPGMA was chosen because it has a higher cophenetic correlation coefficient, less stress and distortion (Table 3).

Table 3. Cophenetic Correlation Coefficient (CCC), stress and distortion of Ward Methods, Nearest Neighbor (NN) and UPGMA for the Zingiber officinale samples.

\begin{tabular}{llll}
\hline & WARD & NN & UPGMA \\
\hline CCC & $0.7945^{* *}$ & $0.8105^{* *}$ & $0.8290^{* *}$ \\
Stress (\%) & - & 21.063 & 9.495 \\
Distortion (\%) & - & 34.04 & 0.90 \\
\hline$* *$ Significant at $1 \%$, by the $t$-test. & & &
\end{tabular}

**Significant at $1 \%$, by the $t$-test.

The dendrogram, which was generated by the UPGMA clustering method and the cutoff point $(0.55-85 \%)$ established by the Mojena procedure (1977), made it possible to separate the 19 individuals of Z. officinale into two main groups (Figure 2A). Group I (GI) represents $37 \%$ of the 19 individuals evaluated, while group II (GII) represents $63 \%$.

The Bayesian analysis carried out by the Structure program corroborates the result obtained by the UPGMA method, and formed two distinct groups $(\mathrm{k}=2)$ (Figure 2B).

In figure $2 \mathrm{C}$, we can observe that the constitution of the groups formed by the UPGMA method and by the Bayesian analysis are not related to the geographic distribution of the individuals. 


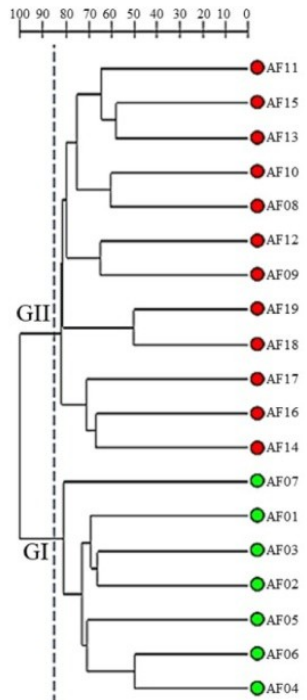

A

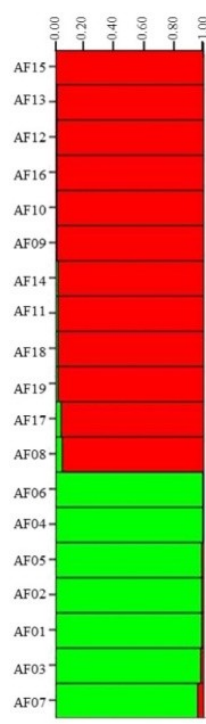

B

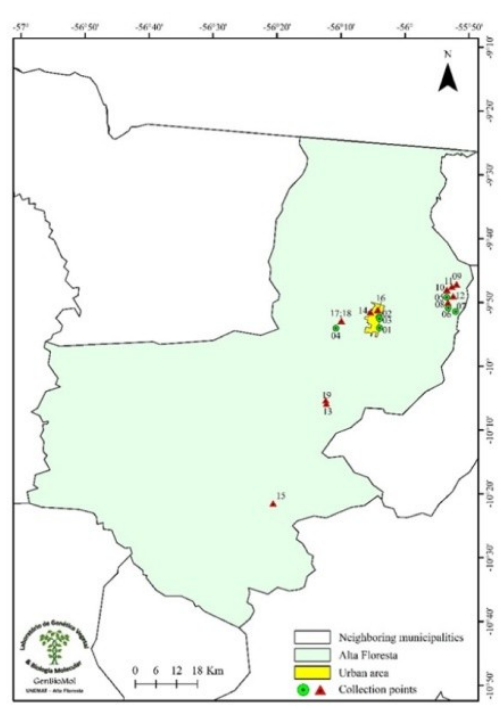

Figure 2. Dendrogram of genetic dissimilarity among the 19 individuals of Zingiber officinale, obtained via the UPGMA method and complement of the Jaccard index as a measure of dissimilarity (A). Grouping of 19 individuals of $Z$. officinale according to molecular bases with nine ISSR primers using Bayesian analysis. Individuals are represented by vertical bars colored according to the group to which they belong ( $\mathrm{K}=2$ groups) (B). Geographic location of the individuals of $Z$. officinale evaluated in this study (C).

The Principal Coordinate Analysis (PCoA) was consistent with the UPGMA clustering method and the Bayesian analysis, placing individuals in two distinct groups, with the first two axes explaining $33.57 \%$ of the total variation (Figure 3 ).

Principal Coordinates (PCoA)

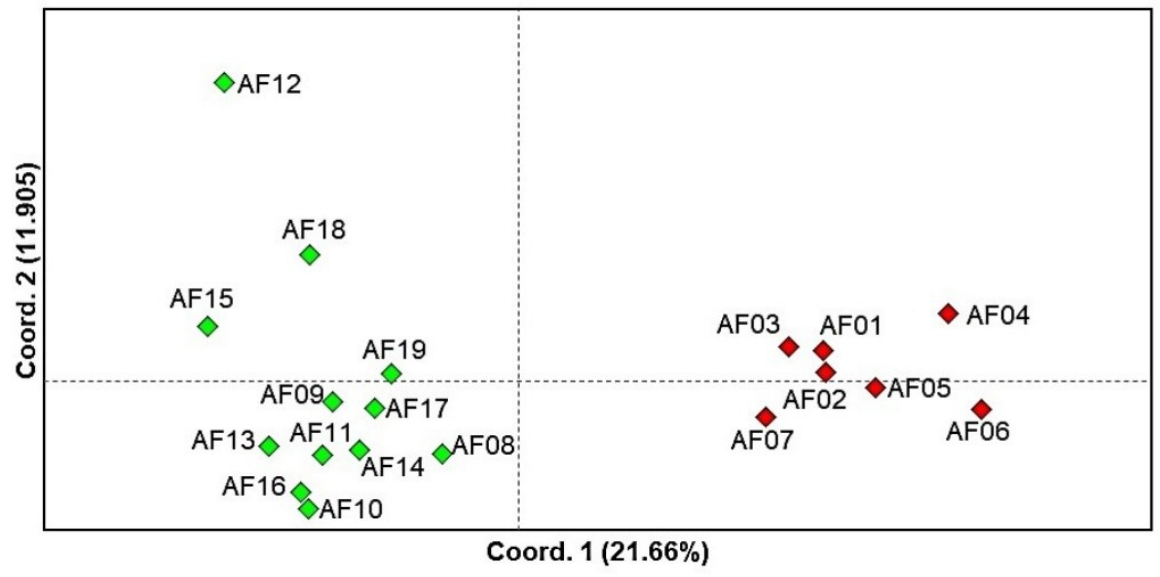

Figure 3. Graphic dispersion based on the analysis of the main coordinates of the 19 individuals of Zingiber officinale obtained in urban and rural backyards in Alta Floresta, Mato Grosso state, Brazil. 
The evaluation of genetic diversity among the groups formed by Bayesian analysis (Table 4) indicates that GI and GII have similar reserves of genetic variability, as indicated by Shannon's index, although GII has a higher percentage of polymorphism.

Table 4. Genetic diversity parameters for the two groups $(\mathrm{k}=2)$, as determined by Bayesian analysis for the 19 individuals of Zingiber officinale.

\begin{tabular}{|c|c|c|c|}
\hline Parameters & Group I & Group II & Total \\
\hline $\mathrm{N}$ & 7 & 12 & 19 \\
\hline $\mathrm{Na}$ & $1.60(0.49)$ & $1.72(0.45)$ & $1.88(0.32)$ \\
\hline $\mathrm{Ne}$ & $1.36(0.37)$ & $1.35(0.36)$ & $1.44(0.33)$ \\
\hline $\mathrm{He}$ & $0.21(0.20)$ & $0.21(0.19)$ & $0.27(0.17)$ \\
\hline$I$ & $0.32(0.29)$ & $0.33(0.26)$ & $0.41(0.23)$ \\
\hline$\% \mathrm{P}$ & 60.26 & 71.79 & 88.46 \\
\hline
\end{tabular}

The analysis of molecular variance (AMOVA) (Table 5) between the two groups indicated that the total variation is greater within the groups and that the value of genetic differentiation of the groups $\left(\mathrm{F}_{\mathrm{ST}}\right)$, with 1023 random permutations, is of approximately $45 \%$.

Table 5. Molecular Variance Analysis (AMOVA) of the two groups $(\mathrm{k}=2)$, as determined by Bayesian analysis for the 19 individuals of Zingiber officinale, using nine ISSR primers.

\begin{tabular}{lccllll}
\hline Source of variation & DF & SS & CV & TV (\%) & F & P \\
\hline Between groups & 1 & 42.154 & 4.18722 & 44.94 & 0.44939 \\
Within groups & 17 & 87.214 & 5.13025 & 55.06 & & \\
\hline Total & 18 & 129.368 & 9.31748 & & \\
\hline Degrees of Freedom (DF), Sum of Squares (SS), Component of Variance (CV), Total Variance (TV), Genetic divergence between the \\
groups. (FST) and probabilities of having a component of variance greater than the values observed at random (P).
\end{tabular}

\section{DISCUSSION}

The percentage of polymorphism found in this study (88\%) (Table 1) confirms the genetic variability among the individuals studied. A similar result was obtained by Pandotra et al. (2015), who analyzed the efficiency of molecular markers in the characterization of $Z$. officinale germplasm. In their study, seven ISSR primers detected $86.61 \%$ polymorphism. However, Prem et al. (2008) used 13 ISSR markers to compare exotic ginger genotypes and found only $35.14 \%$ polymorphism.

The primers used in this study were efficient in detecting the polymorphism of the species, considering that the average value of the polymorphic information content (PIC) was 0.70 and, according to Botstein et al. (1980), primers with PIC greater than 0.50 are classified as highly informative. Molecular markers of a dominant character, such as RAPD and ISSR, have been used in the molecular characterization of $Z$. officinale and presented average values of PIC that were either moderately or very informative (Zambrano-Blanco, 2015). 
The UPGMA hierarchical grouping method was chosen because it was the best for representing the genetic diversity among the individuals of $Z$. officinale which were evaluated in this study, since the CCC (cophenetic correlation coefficient ) showed an association of approximately $83 \%$ between the dissimilarity matrix (complement of the Jaccard index) and the cophenetic matrix, thus showing greater consistency in the clustering pattern. The agreement between the matrices is represented by the $\mathrm{CCC}$ values that, when higher than 0.7 , indicate that the method is satisfactory and adequate for representing the data set (Rohlf, 1970; Cruz and Carneiro, 2003).

The results of this study are in agreement with the findings of Tiago et al. (2016) and Rocha et al. (2017) who, by using ISSR markers to estimate the genetic diversity of Manihot esculenta C. and Hymenaea courbaril L., respectively, obtained higher CCC for the UPGMA method (0.84 and 0.75) than for the NN methods (0.82 and 0.72) and WARD method (0.51 and 0.50$)$. The UPGMA method frequently obtains the highest CCC values and, consequently, less distortion values, since, according to Cruz and Carneiro (2003), they are inversely proportional, or rather, the higher the CCC, the lower the distortion.

The UPGMA and NN methods gave values close to CCC, however, the stress values confirm the efficiency of the UPGMA method, if one considers that stress values $\geq$ 20 are considered bad, while values $<10$ are considered good in determining the accuracy of the adjustment of the dendrogram (Kruskal, 1964) (Table 3).

Although the reproduction of $Z$. officinale is asexual, the different methods used to analyze the structure and genetic distance by the programs Structure, GenAlEx and Genes indicate genetic diversity among the individuals we evaluated. The genetic diversity found in this study represents the variability between genotypes kept in backyards and these can be considered conservation sites on farm. In this sense, our study differs from most studies of molecular characterization of the species, since, according to Kizhakkayil and Sasikumar (2011), these tend to use material from germplasm banks ex situ, and the results obtained are frequently affected by the geographic region of origin.

The UPGMA method also indicates that there is genetic diversity within GI and GII, since they presented subgroups (Figure 2A), which was corroborated by the Shannon Index $(\sim 0.33)$ (Table 4), which varies between 0 and 1 , and the closer to 1 , the greater the diversity. The constitution of the clusters formed by the UPGMA method and by the Bayesian analysis is not related to the geographic distribution of the individuals; in other words, the cultivation site (urban or rural), which can be attributed to the form of propagation of the species (Figure 2). Propagation of $Z$. officinale is carried out by planting the rhizomes, and the properties evaluated in this study only grow ginger for home consumption (for food use or herbal medicine) and, each year, harvest the rhizomes and store part of them for the next planting, which has been repeated for many years, so that many growers can no longer inform the origin of the material. Since it is a species of vegetative propagation, allowing both the exchange of genetic materials between those who cultivate it and the maintenance of the same genotype over time, the genetic diversity found in the evaluated material is the result of mutations and natural selection occurred over the years. Thus, the urban and rural backyards have become deposits of great genetic diversity and at the same time important conservation spaces. When estimating the genetic diversity among $Z$. officinale using RAPD markers, Nayak et al. (2005) obtained similar results; the formation of groups was not directly related to the geographical location of the cultivars. Kizhakkayil and Sasikumar (2010) used RAPD and ISSR markers to analyze the genetic 
diversity of 46 accessions of $Z$. officinale and observed that accessions from the same region presented less genetic distance from each other than when compared with those from other regions.

$\mathrm{F}_{\mathrm{ST}}$ values greater than 0.25 of, as found in this study, indicate high genetic differentiation (Wright, 1978) which may, in the case of ginger, be related to both the process of vegetative propagation and the genetic basis of the material evaluated. Genetic diversity may also be related to the recent colonization process in the municipality of Alta Floresta, which began in the 70s by immigrants from various regions of the country, mainly from the states of Paraná and Maranhão, who brought with them seeds, rhizomes and seedlings of various plant species (Weihs et al., 2017; Cardoso et al., 2018; Fabris et al., 2018; Silva and Rauber, 2018). These results are similar to those found by Blanco et al. (2016) who evaluated the diversity between accessions of Z. officinale from three Brazilian regions and are also similar to the results obtained by Kavitha et al. (2010) who evaluated the genetic variability among accessions of the same species and three more species of the genus Zingiber obtained in southern India. Their results demonstrated that the greatest diversity occurred among accessions and not among respective regions of origin.

The results of this study indicate that ISSR primers were efficient in detecting polymorphism in Zingiber officinale. The clustering methods (UPGMA and Bayesian analysis) which were used revealed the formation of two distinct groups. This formation demonstrated that there is indeed genetic diversity in the analyzed germplasm, that the genetic diversity was greater within the groups and that this was not directly influenced by their geographical distance. The non-occurrence of duplicity indicates that the individuals studied can be used to form an active germplasm collection with the aim of maintaining the diversity and the genetic improvement of the species, and prioritizing the most dissimilar individuals (AF06 and AF12).

\section{ACKNOWLEDGMENTS}

This work was carried out with the support of the Coordination of Improvement of Higher Education Personnel - Brazil (CAPES) Financing Code 001 and the Amazon Fund/BNDES.

We would like to thank the Secretariat of Education of the State of Mato Grosso (SEDUC/MT) for granting a leave of absence for the professional qualification of the first author and to the Postgraduate Program in Amazonian Biodiversity and Agroecosystems, UNEMAT, for allowing the development of this research, which is part of ES Cardoso's Master's dissertation. We would also like to thank all those who have collaborated.

\section{CONFLICTS OF INTEREST}

The authors declare no conflict of interest.

\section{REFERENCES}

\footnotetext{
Adaniya S and Shoda M (1998). Variation in pollen fertility and germinability in ginger. J. Japan. Soc. Hort. Sci. 67(6): $872-874$.

Bered F, Barbosa Neto JF and Carvalho RIJ (1997). Marcadores Moleculares e sua aplicação no melhoramento genético de plantas. Cienc. Rural. 7(3): 513-520.
} 
Blanco EZ, Bajay MM, Siqueira MVBM, Zuchi MI, et al. (2016). Genetic diversity an structure of Brazilian ginger germplasm (Zingiber officinale) revealed by AFLP markers. Genetica. 144(6): 627-638.

Botstein D, White RL, Skolnick M and Davis RW (1980). Construction of a genetic linkage map in man using restriction fragment length polymorphisms. Am. J. Hum. Genet. 32(3): 314-331.

Cardoso ES, Rossi AAB, Pedri ECM, Bispo RB, et al. (2018). Conhecimento e uso do gengibre por familiares de alunos de duas unidades escolares de Alta Floresta/MT. Gaia Scientia. 12(3): 145-154.

Cruz CD (2016). Genes Software - extended and integrated with the R, Matlab and Selegen. Acta Sci Agron. v.38, n.4, p.547-552.

Cruz CD and Carneiro PCS (2003). Modelos biométricos aplicados ao melhoramento de plantas. Viçosa: UFV.

Doyle JJ and Doyle JL (1987). A rapid DNA isolation procedure for small quantities of fresh leaf tissue. Phytochem. Bull. 19(1): 11-15.

Elpo ERS, Negrelle RRB and Rücker NGA (2008). Produção de gengibre no município de Morretes, PR. Scientia Agraria. 9(2): 211-217.

Evano G, Regnaut, S and Goudet J (2005). Detecting the number of clusters of individuals using the software STRUCTURE: a simulation study. Mol. Ecol. 14: 2611-2620.

Excoffier L, Smouse PE and Quattro JM (1992). Analysis of molecular variance inferred from metric distances among DNA haplotypes: application to human mitochondrial DNA restriction data. Genetics. 131: 479-491.

Excoffier L, Laval G and Schneider S (2007). Arlequin (versão 3.0): an integrated software package for population genetics data analysis. Evol. Bioinform. Online. 1: 47-50.

Fabris R, Silva SZ and Terrmann DF (2018). O projeto de reforma agrária que deu origem a cidade de Alta Floresta: uma visão sociológica. JUDICARE. 13(2): 1-16.

Hoffmann LV and Barroso PAV (2006). Marcadores moleculares como ferramentas para estudos de genética de plantas. Campina Grande: Embrapa Algodão, 35p. (Documento 147).

Ismail NA, Rafii MY, Mahmud TMM, Hanafi MM, et al. (2016). Molecular markers: a potential resource for ginger genetic diversity studies. Mol. Biol. Rep. 43(12): 1347-1358.

Kavitha PG, Kiran AG, Dinesh Raj R, Sabu M, et al. (2010). Amplified fragment length polymorphism analyses unravel a striking difference in the intraspecific genetic diversity of four species of genus Zingiber Boehm. from the Western Ghats, South India. Curr. Sci. 98(2): 242-247.

Kizhakkayil J and Sasikumar B (2010). Genetic diversity analysis of ginger (Zingiber officinale Rosc.) germplasm based on RAPD and ISSR markers Sci. Hortic-Amsterdam. 125(1): 73-76.

Kizhakkayil J and Sasikumar B (2011). Diversity, characterization and utilization of ginger: A review. Plant Genet Resour-C. 9(3): 464-477.

Kruskal JB (1964). Multidimensional scaling by optimizing goodness of fit to a nonmetric hypothesis. Psychometrika. 29(1): $1-27$.

Magalhães MT, Koketsu M, Gonçalves SL, Cornejo EP, et al. (1997). Gengibre (Zingiber officinale Roscoe) brasileiro: aspectos gerais, óleo essencial e oleoresina. Parte 2 - secagem, óleo essencial e oleoresina. Food Sci. Technol. 17(2): 132-136.

Mojena R (1977). Hierarchical grouping methods and stopping rules: an evaluation. Comput. J. 20(4): 359-363.

Nayak S, Naik PK, Acharya L, Mukherjee AK, et al. (2005). Assessment of genetic diversity among 16 promising cultivars of ginger using cytological and molecular markers. Z. Naturforschung C. J. Biosci. 60(5-6): 485-492.

Palharin LHC, Figueiredo Neto E, Lopes, MPC and Bosquê GG (2008). Estudo sobre o gengibre na medicina popular. Revista Científica Eletrônica de Agronomia. 7(14): 1-4.

Pandotra P, Gupta AP, Gandhiram, Husian MK, et al. (2013). Genetic and chemo-divergence in eighteen core collection of Zingiber officinale from North-West Himalayas. Sci. Hortic-Amsterdam. 160: 283-291.

Pandotra P, Gupta AP, Khan S, Ram G, et al. (2015). A comparative assessment of ISSR, RAPA, IRAP, \& REMAP molecular markers in Zingiber officinale germplasm characterization. Sci. Hortic-Amsterdam. 194: 201-207.

Peakall R and Smouse PE (2006). GENALEX 6: genetic analysis in Excel. Population genetic software for teaching and research. Mol. Ecol. Notes. 6: 288-295.

Peakall R and Smouse PE (2012). GenAlEx 6.5: genetic analysis in Excel. Population genetic software for teaching and research-an update. Bioinformatics. 28(19): 2537-2539.

Prem J, Kizhakkayil J, Thomas E, Dhanya K, et al. (2008). Molecular characterization of primitive, elite and exotic ginger genotypes to protect the biowealth of elite ginger accessions. J. Spices Aromat. Crop. 17(2): 85-90.

Pritchard JK, Stephens M and Donnelly P (2000). Inference of population structure using multilocus genotype data. Genetics. 155(2): 945-959.

Pritchard JK, Wen X and Falush D (2010). Documentation for structure software: Version 2.3. p.1-38. Available: http://burfordreiskind.com/wp-content/uploads/Structure_Manual_doc.pdf

Rocha VD, Tiago PV, Tiago AV, Pedri ECM, et al. (2017). Genetic diversity among Hymenaea courbaril L. genotypes naturally occurring in the north of Mato Grosso State, Brazil. Genet. Mol. Res. 16(3): gmr16039706

Rohlf FJ (1970). Adaptative hierarchical clustering schemes. Syst. Biol. 19(1): 58-82.

Santonieri L and Bustamante PG (2016). Conservação ex situ e on farm de recursos genéticos: desafios para promover sinergias e complementaridades. Bol. Mus. Para. Emílio Goeldi. Cienc. Hum. 11(3): 677-690.

Genetics and Molecular Research 19 (2): gmr18576 
Silva FF and Rauber M (2018). Memórias, práticas e degradações garimpeiras em Alta Floresta - MT. REFAF. 7(2): 2848.

Sousa LS, Silva ÍRC, Assis DJ, Pascoal DRC, et al. (2013). Estudo prospectivo sobre as propriedades terapêuticas do Zingiber officinale (gengibre) com ênfase na ação antimicrobiana. GEINTEC. 3(5): 427-436.

Tiago AV, Rossi AAB, Tiago PV, Carpejani AA, et al. (2016). Genetic diversity in cassava landraces grown on farms in Alta Floresta-MT, Brazil. Genet. Mol. Res. 15(3): gmr8615.

Weihs M, Sayago D and Tourrande J-F (2017). Dinâmica da fronteira agrícola do Mato Grosso e implicações para a saúde. Estud. Av. 31(89): 323-338.

Wright S (1978). Evolution and Genetics of Populations. Chicago: University of Chicago.

Xavier A, Wendling I and Silva RS (2013). Silvicultura clonal: princípios e técnicas. Viçosa: UFV.

Yeh FC, Yang RC, Boyle TBJ, Y Z, et al. (2000). POPGENE version 1.32: Microsoft Window-based freeware for population genetic analysis. Edmonton: University of Alberta.

Zambrano-Blanco E (2015). Diversidad genética del jengibre (Zingiber officinale Roscoe.) a nivel molecular: Avances de la última década. Entramado. 11(2): 190-199. 